\title{
QUEEN'S
UNIVERSITY
BELFAST
}

\section{Joining together or pushing apart? Building relations and exploring difference through shared education in Northern Ireland}

Loader, R., \& Hughes, J. (2017). Joining together or pushing apart? Building relations and exploring difference through shared education in Northern Ireland. Cambridge Journal of Education, 47(1), 117-134.

https://doi.org/10.1080/0305764X.2015.1125448

\section{Published in:}

Cambridge Journal of Education

\section{Document Version:}

Peer reviewed version

Queen's University Belfast - Research Portal:

Link to publication record in Queen's University Belfast Research Portal

\section{Publisher rights}

Copyright 2016 Taylor and Francis. This work is made available online in accordance with the publisher's policies. Please refer to any applicable terms of use of the publisher.

\section{General rights}

Copyright for the publications made accessible via the Queen's University Belfast Research Portal is retained by the author(s) and / or other copyright owners and it is a condition of accessing these publications that users recognise and abide by the legal requirements associated with these rights.

Take down policy

The Research Portal is Queen's institutional repository that provides access to Queen's research output. Every effort has been made to ensure that content in the Research Portal does not infringe any person's rights, or applicable UK laws. If you discover content in the Research Portal that you believe breaches copyright or violates any law, please contact openaccess@qub.ac.uk. 


\title{
Joining together or pushing apart? Building relationships and exploring difference through shared education in Northern Ireland.
}

\begin{abstract}
In divided societies, the promotion of cross-cultural contact through the education system has been central to efforts to improve intergroup relations. This approach is informed by an understanding of the contact hypothesis, which suggests that positive contact with a member of a different group should contribute to improvements in attitudes towards the group as a whole. While a substantial body of research provides support for contact theory, critics have argued that its emphasis on harmonious encounters can result in the neglect of group differences and associated issues of conflict and discrimination during contact. The research discussed in this article explores this tension with reference to two shared education projects in Northern Ireland. Research data, gathered primarily through interviews with pupils, confirms that divisive issues are rarely addressed during contact and explores several influences on this: the nature of pupils' relationships, the programme structure, and the prevailing social norms of avoidance.
\end{abstract}

Keywords: Social cohesion, intergroup contact, faith schools, intercultural education

\section{Introduction}

In plural societies, particularly those with experience of ethnic and religious division, the existence of faith-based education continues to be highly contentious. In England, concerns about the impact of faith schools have been evident in the media and political responses to socalled 'race riots' in Bradford and Oldham in 2001 and recent anxieties about 'Islamic radicalism' in secular and Muslim schools (Dugan, 2014; Home Office, 2001; Mears and Ibrahim, 2005), the latter leading to the publication of guidance on the teaching of 'British values' in schools (Department of Education, 2014). In Scotland, ongoing concerns about sectarianism have been manifest in criticism of state-funded faith schools, most of which are managed by the Catholic church, for entrenching religious segregation (Conroy, 2001; Flint, 2012). In Northern Ireland, which experienced 30 years of conflict along ethno-religious lines, the education system has perhaps been particularly contentious because its separation along denominational lines - that is, between controlled/Protestant and maintained/Catholic 
schools - reflects the major fracture within Northern Irish society as a whole (Gallagher, 2004; Grayling, 2005).

In each of these cases, assertions that faith schools are divisive have been challenged by religious organisations and supporters of faith-based education. Proponents contend that separate education is a manifestation, not a cause, of wider social division and hostility (Gallagher, 2005; Halstead and McLaughlin, 2005), with faith schools providing an environment in which the traditions and cultures of threatened minorities can be protected and nurtured (Shah, 2012; Flint, 2007; Miller, 2001). Advocates argue, moreover, that faith schools contribute positively to social cohesion as a result of their religious commitments to values such as love, social justice and reconciliation (Catholic Bishops of Northern Ireland, 2001; Grace, 2012). There is consequently little consensus on the relationship between faith schooling and social division, and, as Hughes (2011) notes, the body of evidence in this area remains limited. There has, however, been more widespread agreement about the role of schools in addressing conflict and, to this end, policymakers and educationalists have largely advocated a two-fold approach.On one hand, they have promoted the development of shared values and intercultural understanding through the curriculum; and on the other hand, they have sought to provide opportunities for cross-cultural contact, either through school twinning initiatives or by increasing the ethnic diversity among the intake of individual schools. This article focuses on initiatives of the second type and concentrates on the experience of Northern Ireland, where the promotion of contact between Catholic and Protestant pupils has been a feature of education policy since the early 1980s. Via the foundation of integrated schools and the implementation of contact schemes and collaborative working between separate schools, educationalists and others have aimed to promote improvements in relations by providing opportunities for pupils to meet and build relationships across the historical community divide.

Contact initiatives such as these are each predicated to some extent on an understanding of the contact hypothesis. Commonly attributed to Gordon Allport (1958), this suggests that contact with a member of a different group (most commonly a different religious or ethnic group) should result in more positive attitudes towards the group as a whole. While a substantial body of literature supports the premise that cross-group interaction can promote more positive intergroup attitudes (see Pettigrew and Tropp, 2006), recent research has indicated the possible limitations of contact as a means of improving and transforming group 
relations. In particular, studies have pointed to the tendency of participants - particularly those from advantaged social groups - to focus on intergroup similarities during contact and avoid potentially divisive issues. While this can help to facilitate harmonious encounters and the type of positive relationship valued by many contact theorists, it may also impede the exploration of difference that is likely to be necessary to challenge social division and inequality, and, in contexts emerging from conflict, to promote reconciliation.

This article explores this tension between harmony and reconciliation with reference to contact through one of the initiatives currently operating in Northern Ireland, shared education. A relatively recent development, shared education programmes encourage collaboration between Catholic and Protestant schools to deliver classes and activities for mixed groups of students across the school sites. Employing qualitative methods, principally interviews with participants in shared education projects, this paper seeks to explore the extent to which shared education, firstly, facilitates positive encounters and the development of friendships, in accordance with the principles of contact theory; and secondly, addresses issues of political, religious and cultural difference. The article considers, further, how these two aspects of the programme relate to one another.

\section{The principles and practice of shared education}

Formally introduced in Northern Ireland in 2007, shared education involves the development of collaborative partnerships between existing controlled/Protestant, maintained/Catholic, and integrated schools to provide joint curriculum-based classes and activities. These take place on a regular basis - typically at least once a week for a year at post-primary level - with pupils at each institution moving between participating schools to undertake the relevant subject or activity in mixed groups. Shared education thus seeks to provide frequent, sustained opportunities for Catholic and Protestant pupils to meet and build relationships, with the aim of promoting more positive attitudes and thereby challenging existing patterns of separation and division. Recognising the financial and curricular imperatives facing schools, shared education also aims to extend and improve educational provision and promote financial savings by reducing duplication (Duffy and Gallagher, 2014; Hughes, Lolliot, Hewstone, Schmid and Carlisle, 2012).

The model of shared education, which creates interdependence between separate schools but does not require formal school integration, has been positioned as an intermediary between 
separate and integrated schools. While recognising that, due to parental preference, residential segregation and political and religious interests, a significant expansion in the formally integrated sector is unlikely in the short-term, shared education also reflects a view that this should not preclude pupils at separate schools from meeting and learning alongside those from the other religious tradition (Hughes et al., 2012; Knox, 2010). While such opportunities have previously been offered through cross-community contact programmes, most notably the Schools Community Relations Programme that ran until 2010, shared education seeks to ensure more regular and high quality contact than these earlier programmes achieved (O’Connor, Hartop and McCully, 2002; Richardson, 2011; Smith and Robinson, 1996), and thus to effect more substantial attitudinal change.

As a formal initiative, shared education in Northern Ireland has largely developed through three projects, each funded by Atlantic Philanthropies and the International Fund for Ireland. These are the Primary Integrating and Enriching Education Project (PIEE), delivered by the North Eastern Education and Library Board; the Shared Education Programme, coordinated by the Fermanagh Trust for primary and post-primary schools in Fermanagh; and the Sharing Education Programme (SEP), managed by Queen's University. The latter has involved more than 100 schools to date, across two cohorts (2007-2010 and 2010-2013), and is the focus of this article. From its outset, individual SEP partnerships have been encouraged to develop programmes of classes and/or activities that address the educational priorities of participating schools; in practice, schools have frequently chosen to collaborate to deliver courses leading to examinations at 16 and 18 . The only stipulation has been that these classes and activities should promote 'sustainable, high quality engagement by young people from different backgrounds” (SEP, 2008), enabling pupils to build positive relationships.

This emphasis on high-quality engagement and the development of relationships reflects, in part, the influence of contact theory on the model of shared education. As discussed below, a substantial body of evidence provides support for the positive effects of contact on prejudice and thus for the theory of change underpinning SEP and similar programmes. Although some commentators have expressed concerns about the amount of contact pupils experience via shared education (Alliance Party, 2013; IEF, 2013), there is reason to believe that contact at the level promoted through SEP can have an important impact. Given the depth of segregation in Northern Ireland, young people attending separate schools often have limited opportunity for cross-community encounter: a survey of 821 SEP participants found, for 
example, that two-fifths had never (knowingly) met anyone from the other religious group before attending shared classes (Gallagher et al, 2010). By encouraging collaboration between separate schools, shared education can disrupt this pattern and provide opportunities for sustained contact that would otherwise be unavailable. Research shows that an increase such as this in the opportunity for contact is associated with a higher number of outgroup friendships, and, via this mechanism, lower levels of prejudice, with contact effects most substantial among those with limited prior experience of the outgroup (Al Ramiah et al, 2012; Turner, Hewstone and Voci, 2007).

\section{Contact theory}

The contact hypothesis is commonly attributed to American psychologist Gordon Allport (1958), although the impact of intergroup contact on individuals' attitudes towards different ethnic groups - or 'outgroups' - had attracted increasing scholarly attention in the United States during the 1930s and 1940s (see Dovidio, Gaertner and Kawakami, 2003, for a review). Against the background of these studies, which suggested that contact with an outgroup member could promote more positive racial attitudes, Allport (1958, p.267) formulated his hypothesis thus:

Prejudice (unless deeply rooted in the character structure of the individual) may be reduced by equal status contact between majority and minority groups in the pursuit of common goals. The effect is greatly enhanced if this contact is sanctioned by institutional supports (i.e. by law, custom or local atmosphere), and provided it is of a sort that leads to the perception of common interests and common humanity between members of the two groups.

In the years that followed, work in the field of contact focused largely on testing Allport's hypothesis and the role and relative contributions of the four 'optimal' conditions that he proposed: equal status between group members, common goals, intergroup cooperation and institutional support. Collectively, as demonstrated by Pettigrew and Tropp's (2006) metaanalysis of 515 studies, this research provides strong empirical support for the premise the contact can reduce prejudice. The same work also found that contact had a more substantial impact when Allport's facilitating conditions were present, although it was nonetheless effective in their absence. 
A feature of Pettigrew and Tropp's (2006) meta-analysis is the authors' use of 'friendship contact' as an indirect indicator of Allport's four conditions. Within contact theory, friendship has been particularly valued as providing the type of high-quality contact that can most effectively promote attitude change (Pettigrew, 1997, 1998). Indeed, research that has compared friendship with less intimate forms of contact has found the former to have a more substantial impact on prejudice (Herek and Capitanio, 1996; Pettigrew, 1997). Over the past 15 years or so, friendship has gained additional status in contact theory as studies have identified the role of affective processes in mediating the relationship between contact and attitudes. Recent research has, for example, highlighted the specific mediating role of processes such as empathy, anxiety and self-disclosure during contact (Harwood, Hewstone, Paolini and Voci, 2005; Pettigrew and Tropp, 2008; Turner, Hewstone and Voci, 2007).

While contact, particularly via cross-group friendship, is thus well established as a means of improving intergroup attitudes, contact theory has not been not without its critics. One of the most significant areas of criticism concerns the assumptions on which contact theory rests i.e. that discrimination and conflict arises (at least in part) from faulty or irrational beliefs about outgroup members and may be substantially diminished once these beliefs are corrected through contact. This perspective has been criticised for paying too little attention to alternative explanations of discrimination and conflict, including the possibility that this may stem from a rational desire to protect the social, economic and political advantages enjoyed by one’s own group (Dixon, Durrheim and Tredoux, 2005; Forbes, 2004; Jackman and Crane, 1986). In this regard, contact theory has also been criticised for its focus on individual-level attitudes and its neglect of the role of social structures and discourses that sustain prejudice and inequality (Connolly, 2000; Dixon, Durrheim and Tredoux, 2005; Erasmus, 2010).

Research has given further credence to criticism of this type, suggesting that, among majority group members, contact has only a modest effect on support for measures to promote equality (Dixon, Durrheim and Tredoux, 2007; Jackman and Crane, 1986; Saguy, Tropp and Hawi, 2013) and, among minority group members, may actually reduce support for such measures (Dixon, Levine, Reicher and Durrheim, 2012; Dixon, Durrheim, Kerr and Thomae, 2013; Wright and Lubensky, 2009). Moreover, studies have shown that issues of difference and inequality tend to receive little attention during contact, with participants - particularly among the majority group - preferring to focus on similarities and avoid the tension and 
uncertainty that may accompany the discussion of divisive issues (Maoz, 2011; Saguy, Dovidio and Pratto, 2008). While this might promote the harmonious encounters advocated by many contact theorists, there remain questions over the potential of contact of this type to transform relations, as the intergroup differences that are central to conflict and discrimination are likely to remain unaddressed.

\section{The current research}

Shared education in Northern Ireland provides a valuable setting through which to explore the apparent tension between promoting harmony and transforming relations. While relationship-building is central to shared education, publications from the Sharing Education Programme (SEP) coordinated by Queen's University also suggest that shared education is envisaged as a forum for the exploration of intergroup difference. The Programme's promotional booklet, for example, features accounts which refer to a 'direct focus on issues of reconciliation' within shared education and 'creating a space where...young people are allowed to talk about identity, Catholics and Protestants, community and culture' (SEP, 2008). According to this perspective, contact should not only enable the development of friendships, but also facilitate the type of intercultural dialogue that scholars have considered central to 'thick' reconciliation - i.e. that which involves forgiveness, justice, and the transformation of social relations (Aiken, 2010; Rouhana, 2010; Skaar, 2013). While shared education does not specify how such issues should be introduced, two mechanisms appear plausible: firstly, that such issues will arise naturally as pupils develop cross-group friendships via shared classes; and secondly, that these topics will be introduced during lessons, with teachers making links between the curriculum material and relevant issues in Northern Ireland.

To explore whether and how shared education enables the development of friendship and the exploration of difference, the research adopted a case study approach and employed qualitative methods to explore processes of contact in two shared education partnerships, which have been given the pseudonyms of 'Bellevue' and 'Whitecliff'. Each partnership comprised two schools - one Catholic, one Protestant - which jointly provided exam courses and activities for pupils on either school site. The partnerships, which were both located in small coastal towns (population 5,000-6,000), were chosen because of the contrasting nature of the local relations and the different histories of collaboration between the schools. While relations in Whitecliff were considered to be largely positive and harmonious, in Bellevue 
they were strained and marked by occasional sectarian incidents. In Whitecliff, moreover, collaboration between the two schools was well-established and extensive: all post-16 provision was shared and SEP funding had additionally enabled shared classes in technical, creative and vocational subjects to be offered at Key Stage 4. In Bellevue, by comparison, collaboration between the schools was a recent development and involved only two courses, one leading to a vocational qualification in engineering and the other to the award of a Certificate of Personal Effectiveness (CoPE).

While research on contact has typically utilised quantitative methods, a qualitative approach was selected for this study in response to calls for research that can elucidate processes of contact rather than inputs and outcomes, and pays greater attention to the 'interpretive frameworks and practices’ employed by participants 'to make sense of their everyday relations' (Dixon, Durrheim and Tredoux, 2005, p.704). Data were collected primarily through semi-structured group interviews with 60 students, aged 14-18. Thirty-two students were interviewed in Whitecliff (17 from the Catholic school, 15 from the Protestant school) and 28 in Bellevue (16 Catholic, 12 Protestant). Each interview involved between two and four pupils and all were interviewed with others from the same school. The interviews were supplemented by one-to-one interviews with teachers (four in Whitecliff, three in Bellevue) and observations of 12 classes and shared activity sessions. Interviews were transcribed and all data were subjected to thematic analysis, as outlined by Braun and Clarke (2006).

\section{Results}

\section{The development of relationships}

As described above, shared education's theory of change supposes that contact will facilitate the development of positive relationships - ideally friendships - which in turn will promote more favourable intergroup attitudes. To explore whether shared education fostered this type of more intimate relationship, the research examined the nature of the interaction that developed in shared classes and the types of relationship that resulted. Whereas quantitative studies of contact typically ask respondents about their number of cross-group friends or assess the quality of contact using measures of 'closeness', 'pleasantness' and/or ‘cooperativeness’ (Brown, Eller, Leeds and Stace, 2007; Islam and Hewstone, 1993; Tam, Hewstone, Harwood, Voci and Kenworthy, 2006), participants in this research were asked only to describe, in their own words, the relationships that they had forged through shared 
education and the factors that they felt had assisted or impeded the development of friendships.

While pupils commonly identified 'meeting new people' or 'making new friends' as benefits of shared education, it was apparent that most had not formed the type of relationship that might constitute 'friendship': of the 60 pupils interviewed, only ten (four in Whitecliff and six in Bellevue) described developing a close interpersonal relationship through shared classes and activities. These pupils spoke of discovering shared interests and reported a level of intimacy that was not present in the relationships described by other students. They were also the only students to report that they had arranged to meet their outgroup friends outside the school.

Well, one of the guys in my music class, I'm in a band with him now, so [our relationship]'s pretty close. I only met him this year, but he had the same sort of musical taste and, like, taste in everything that I did, so we just hit it off right away, and around December time we decided we'd just start a band together so we've had a pretty close relationship. (Boy, Catholic school, Whitecliff)

In comparison, by far the most common relationship was what might be termed ‘acquaintanceship’ and was described by $37 \underline{38}$ pupils (22 in Whitecliff and 15-16 in Bellevue). These relationships varied in nature: while some pupils participated in social conversations within their classes and attended occasional activities at one another's schools, other pupils' interactions had focused primarily on schoolwork and their acquaintanceship was at a relatively early stage. In all cases, however, the relationships were casual and were confined to the classroom. Pupils referred directly to the lack of closeness in these relationships when asked about the possibility of meeting outside school, stating that their relationships with pupils from the other school had not reached the level of intimacy necessary to move outside the classroom.

Amy: If you see them in the street, you say hi. You wouldn't- well, I don't go out shopping or anything.

Victoria: No.

Interviewer: You don't...? 
Amy: I wouldn't go out shopping or anything with them. Don't know them that well. (Protestant school, Whitecliff)

Interviewer: Would you ever see them outside school?

Lisa: No.

Siobhan: Sometimes, up in the town or whatever, maybe...But we wouldn't be close enough to have a day [together], like.

Interviewer: Right, sort of close enough friends?

Siobhan: No. (Catholic school, Bellevue)

Perhaps of greatest concern from the perspective of contact theory was that 12 pupils (six in Whitecliff and six in Bellevue) described students from the partner school as still being relative 'strangers', even after a year or more in the same class. These pupils reported knowing little more about the other students than their names, and in some cases did not know even this. They had exchanged at most only a few words with pupils from the other school, usually in relation to the content of the lesson, and felt that they would struggle to hold a social conversation.

Interviewer: Do you feel you've got to know people from the other school who you didn't know before?

Kevin: I haven't talked to one of them since I came.

Interviewer: Really?

Kevin: Yeah. I've never even said one word to them. (Catholic school, Bellevue)

During the interview conversations and classroom observations, it became clear that the diverse nature of relationships could not be attributed only to differences in pupils' characters or their inclination to form friendships. Also relevant was the scope within shared classes for pupils to interact, begin to learn about one another and build rapport. Opportunities for classroom-based interaction were especially important as pupils rarely spent time together outside the classroom: they returned to their own schools immediately after the classes had ended and were unlikely to meet locally as a result of residential segregation, poor public transport, and the limited provision of 'shared' venues and activities beyond the school. The opportunities for interaction during shared classes were not consistent, however; rather, they 
depended on factors including the nature of the subject, the size and composition of the class, and the willingness of the teacher to facilitate interaction.

In terms of the subject, classes which featured significant group work - such as drama, physical education and CoPE - appeared more favourable to relationship-building, as they required pupils to work collaboratively and interact extensively. In comparison, subjects such as engineering and science tended to be taught in a more didactic fashion, with interaction occurring largely between the teacher and the pupils, and rarely on a pupil-to-pupil basis.

Grace, Joseph and I, the three of us do drama. It's not really a normal class situation, you sort of do have to interact with everybody, so it's a really good subject if you want to get to know someone. (Boy, Catholic school, Whitecliff)

You always find out different things about them [in CoPE]. Like, you'd say you would know everything about them now, like most of their interests and stuff, and then they'll come out with something in class and you would be like, 'oh, you do that?' (Boy, Protestant school, Bellevue)

Similarly, smaller classes generally permitted more extensive and intensive interaction as they tended to foster a more relaxed and intimate atmosphere. In smaller groups, pupils were also less likely to be surrounded by friends from their own school, and were thus obliged to form relationships with pupils from the other school to avoid the awkwardness of isolation. By contrast, in larger classes, pupils tended to sit and interact with friends from their own school.

It's definitely easier to make friends if you're in a smaller class, cos you have to kind of stick together, but if you're in a bigger class, with all your own friends from your own school, then you tend to stick to them. (Girl, Protestant school, Whitecliff)

The teachers' role in supporting and encouraging interaction was also significant, especially as the traditional classroom norms of silence and individual working have typically discouraged communication between pupils. Contact tended to be more frequent and of greater depth where teachers were attentive to the classroom environment and arranged desks and chairs in patterns that enabled and encouraged interaction, i.e. with pupils sitting around 
a large central table or at desks set out in a horseshoe shape. The quality and quantity of contact was also more substantial where teachers were proactive in facilitating interaction, especially in the early stages of shared education. Teachers' willingness to take on this role varied: while some were confident about doing so, others feared that encouraging pupils to interact would mean the loss of valuable teaching time, particularly ahead of exams, or might veer into the discussion of sensitive issues that they felt ill-equipped to address, particularly in the absence of preparative training.

This variation between classes also meant that pupils had quite different experiences, depending on their subject choices: while some had extensive opportunities to build relationships, others had much less chance for interaction with outgroup members in the classroom, often developing only casual acquaintanceships or sometimes remaining relative strangers. While this is not to overlook the progress that even nascent relationships represented in areas characterised by division, it may raise questions about the potential of shared education, in its current form, to foster the kinds of intimate relationships thought most effective in changing attitudes and patterns of relations.

\section{Addressing difference through shared classes and activities}

Over the course of the interviews, pupils were asked about their perceptions and experiences of 'difference' during shared classes and activities. The term 'difference' here covered a broad range of community-related differences, including those concerning religious belief and practice, political views, and cultural activities, as well as associated experiences, such as conflict and inequality. Pupils were invited to discuss both their feelings about addressing these issues through shared education and their personal experiences of doing so.

\section{Feelings about addressing difference}

Pupils spoke most frequently of feelings of awkwardness in relation to addressing difference, and preferred to avoid such subjects, with more than half of interviewees across both partnerships indicating that these issues would not be raised among students. While a minority of this number framed this in terms of passive avoidance, suggesting that group differences simply did 'not really come up' in their classes, most depicted this as a more active process, requiring some care in one's choice of conversation topic. 
Well, we've never really had the experience, I suppose, of talking about, like, different subjects. Like, we wouldn't ever talk about what football team do you support or, like, nobody would say that they preferred hurling to hockey or, like, do you know, that sort of way? ${ }^{1}$ We'd never go into the terms of treading on anybody's toes. It would just be general conversation, trying not to offend people. (Girl, Catholic school, Whitecliff)

When asked why they preferred not to discuss these issues, pupils spoke most commonly of a desire to avoid giving offence and indicated that simply acknowledging the existence of certain community differences could be construed as intimidating and provocative. Fearing that they might provoke tension or accusations of sectarianism by raising such matters, pupils chose instead to focus on uncontentious topics such as the hobbies and interests that they shared. Indeed, their concerns in this regard appeared to extend to the interview, with students seeming anxious to emphasise the similarities between Catholics and Protestants and avoid creating a perception that they held sectarian views.

While the general tendency was thus strongly towards avoidance, there were nuances within this. Most significantly, there was widespread agreement that certain differences provoked less sensitivity than others and were therefore more likely to be broached. Among these were religious practices and certain cultural differences, particularly those relating to sport: just under half of the 60 interviewees spoke of some experience of difference in shared classes, and more than two-thirds of these conversations (including those initiated by pupils themselves) related either to religion or culture. The most delicate subjects, and most studiously avoided, were those relating to political and constitutional issues and the conflict. Interviews yielded only one example of these matters being raised spontaneously by young people themselves, reflecting the widespread anxiety that such topics raised in mixed groups. This preference to focus on less sensitive subjects suggested that, even when they appeared to

\footnotetext{
${ }^{1}$ In Northern Ireland, support for particular football teams tends to reflect community background. This is perhaps most notable in the case of the two major Glasgow-based clubs, Celtic and Rangers: while Celtic has a largely Catholic following, Rangers' fans tend to be drawn from the Protestant community. Moreover, particular sports and games are commonly associated with one group or the other. Hockey and rugby are generally regarded as 'Protestant' /'unionist' sports and are played more frequently at Protestant schools, while hurling and Gaelic football are considered 'Catholic' L'nationalist' sports and are rarely played in nonCatholic schools.
} 
be tackling contentious issues directly, pupils and teachers still employed strategies of avoidance.

In addition to selecting their discussion topics carefully, pupils in more than a third of interviews spoke of being cautious in their choice of conversation partner and were careful to ascertain other students’ views and likely responses before entering any discussion of potentially controversial issues. These pupils indicated that they would only introduce difference as a conversation topic if they could be certain that others would not misinterpret their intentions and think that they were being deliberately provocative.

Interviewer: Do you ever talk about the different traditions that you have?

Orla: Erm, not really, no. It doesn't really come up in conversation.

Roisin: You wouldn't really bring it up.

Sean: Well, you can go onto them about Celtic and Rangers, just joking...

Roisin: Yeah, like, taking the hand ${ }^{2}$, but you need to sort of be careful.

Orla: You don't know how strong people's opinions are. Even if you're really open, you never know how they're going to react to whatever you say to them. (Catholic school, Whitecliff)

For a student to be able to predict another's reaction required a certain level of intimacy between them; however, as outlined in the previous section, most pupils lacked this level of familiarity with outgroup classmates and were therefore reluctant to address any potentially divisive subjects. Pupils also indicated that they would only enter such discussions when they were sure that the other party did not hold strongly to a particular view or community identity (British or Irish, loyalist or republican), so as to avoid provoking arguments. This could result in a somewhat ironic situation where pupils were unlikely become involved in a discussion of community differences with classmates who (openly) held a contrasting perspective to their own.

\section{Experiences of encountering difference}

Despite the general preference to minimise difference between members of the two groups, 27 pupils (11 in Whitecliff and 16 in Bellevue) mentioned some encounter with difference

\footnotetext{
${ }^{2}$ In Northern Irish vernacular, 'taking the hand' means 'to tease' or 'to make fun of something'.
} 
during shared education. These took place across a range of settings - in induction sessions, in private conversations between pupils in class, in lessons, and during extra-curricular activities - and varied in nature according to the circumstances in which they arose. In line with pupils' preference to focus on non-contentious issues, their personal conversations relating to intergroup differences had almost exclusively addressed the 'safer' topics of religion and sport; in only two cases did pupils mention addressing other topics, such as the British royal family and the protests that had, in 2012/13, followed Belfast City Council’s decision to restrict the flying of the Union Flag from its City Hall. It was also striking that, in the majority of these conversations, the discussion focused on the exchange of factual information about religious practices and leisure pursuits. Rarely did pupils feel confident about exchanging personal perspectives and opinions in their social conversations with students from the other school.

Discussions of more contentious subjects tended to be confined to adult-led activities, particularly the induction sessions which preceded the shared classes and were led by specialist facilitators in intercultural dialogue. These sessions were particularly notable for providing the only reported occasions on which the sensitive issue of national identity was raised. For example, during one activity pupils were invited to move to different parts of the room according to whether they considered themselves to be British, Irish or Northern Irish. Reflecting the sensitivity associated with this subject, students who had participated in these tasks reported that they had felt very uncomfortable, and there was a general consensus among interviewees that such activities should have been avoided in a mixed group.

Natalie: They did a thing where you had to sit on the floor and you had to decide whether you thought you were British, Irish or Northern Irish.

Leah: So of course, a lot of the [Catholic school] ones went to Irish and then it was, like, a mix: a few went to British and most people went to Northern Irish, didn't they? Interviewer: OK. And what was that like, doing that?

Leah: It felt very awkward.

Natalie: I didn't really like it. I thought it was a bit awkward. I don't think we should've done that.

Leah: Cos they're meant to be joining us all together and then they just basically separated us all. (Protestant school, Bellevue) 
Discussion of more sensitive issues also occurred in formal classroom activities, although it was relatively rare. While one notable example included a shared politics class that had explored the causes of the flag protests and encouraged the exchange of perspectives among pupils, lessons - like social conversations - tended to address the less contentious aspects of difference, where they addressed it at all. As with the provision of opportunities for interaction, opportunities to discuss difference varied according by subject and teacher. While the nature of certain subjects - such as PE and politics - made such topics unavoidable, more technical and scientific subjects were considered less amenable to the exploration of cultural and religious matters.

I sat down and worked out, well, how am I going to use this in my [politics] classes for bit of debate, and we had a couple of lessons where we looked at, well, why has it [the flag protest] happened, what's the underlying thing, and that was very interesting, because in the class I had very strong opinions and had some great background, you know. (Teacher, Protestant school, Whitecliff)

My subject's engineering, so it's very rarely would we have that type of topic coming up. Maths, talking about machines, it's never really going to be there, you know, unless something's just randomly come up, like some type of comment or something. (Teacher, Catholic school, Bellevue)

Moreover, in the absence of training in teaching controversial issues, teachers appeared unsure how to introduce such topics, with some uncomfortable about doing so in case this raised tensions among pupils. As a result, they were reluctant to challenge the prevailing culture of avoidance, and frequently acquiesced to it.

\section{Discussion}

Two key points emerge from the findings above, the first relating to the nature of the relationships that develop via shared education. Whereas contact theory valorises friendship contact for providing the intimacy and supportive conditions that can help to reduce prejudice (Feddes, Noack and Rutland, 2009; Pettigrew, 1998; Turner, Hewstone, Voci, Paolini and Christ, 2007), it was apparent from pupils’ descriptions that most had not developed this type of close relationship as a result of participating in shared classes and activities. This was due partly (at least) to the lack of opportunities for participants in many classes to engage in 
social interaction - with inhibiting factors including an unsympathetic classroom design, didactic teaching style, or large class size - and has implications for the potential of shared education to effect changes in intergroup relations. While previous research has indicated that, on average, participation in shared education has a positive effect on attitudes (Hughes, Donnelly, Hewstone, Gallagher and Carlisle, 2010; Hughes et al, 2012), the findings from Whitecliff and Bellevue suggest that, in at least some partnerships, the potential of shared education is not being fully exploited. While the acquaintances that constituted the majority of relationships in Whitecliff and Bellevue represented a positive development, the provision of more opportunities for social interaction might help to deepen these relationships and foster the trust and affective emotions associated with attitude change (Pettigew and Tropp, 2008; Tam, Hewstone, Kenworthy and Cairns, 2009; Swart, Hewstone, Crisp and Voci, 2011).

Secondly, it was evident that shared education had not provided substantial opportunities for pupils to explore issues relating to difference and discrimination - that is, those subjects that are central to conflict and division in Northern Ireland and thus to any programme that seeks to promote reconciliation. In part, this reflected the difficulties of introducing such matters during shared lessons, whether due to the lack of a clear link with the curriculum content (particularly in scientific and technical subjects) or because teachers were reluctant to raise contentious issues. Also significantly, in the absence of intimate cross-group relationships, pupils were reluctant to broach topics such as politics or religion. While they felt that such matters could be discussed with close friends, young people were wary of introducing them in more nascent relationships for fear of threatening the fragile harmony between participants. Pupils thus appeared to consider intergroup dialogue inimical to relationshipbuilding, a perception that persisted in the absence of a structured approach to exploring difference through shared education.

These findings echo those of previous research regarding group differences in contact. In identifying a wish to preserve harmonious relations by avoiding the discussion of group differences, this study echoes the findings of Saguy et al (2008), with one notable difference: while Saguy and colleagues' study found that only advantaged group members wished to focus on similarities (with disadvantaged groups preferring to discuss differences and challenge inequality), the current research found that both groups generally wished to concentrate on the aspects they shared in common. While this might reflect the existence of 
greater intergroup equality in Northern Ireland than in the contexts studied by Saguy and colleagues, it also indicates the high level of anxiety and avoidance that surrounds difference in the post-conflict context. In this respect, the current research echoes the findings of Donnelly (2004, 2012), Hargie (2014) and others, who have similarly identified a high level of anxiety and evasion in relation to contentious issues in mixed settings, with Donnelly (2004, p.12) observing that it is 'deemed socially gauche' to introduce such topics in mixed company. In highlighting pupils’ concerns that, by introducing difference, they might provoke offence or, crucially, appear 'sectarian', the current research helps to elucidate the processes underlying this avoidance.

The key challenge facing shared education appears, therefore, to be to find a way to reconcile relationship-building and the exploration of difference. While the foregoing discussion suggests that there are risks associated with introducing potentially contentious issues into the shared class, the preference to focus on creating harmonious relationships at the expense of addressing difference may also have negative consequences. For example, it may foster forms of contact that require pupils to mute the legitimate expression of their opinions or identities (Emerson, 2012), limit pupils’ opportunities to develop skills of conflict resolution (Schofield, 1986), and reduce the scope to challenge discrimination and the structures and narratives which propagate it (Connolly, 2000; Dixon, Durrheim and Tredoux, 2005; Maoz, 2011; Nagda, Yeakley, Gurin and Sorensen, 2013).

To increase the potential of shared education to fulfil both relationship-building and reconciliation goals, those with responsibility for programme delivery might consider two areas for action. The first of these is the enhancement of the 'friendship potential' of shared education, particularly by increasing opportunities for social interaction in shared classes and at other points - such as break times - during the school day. This may enable pupils to forge more intimate relationships, which are associated in contact literature with greater attitude change and appeared more conducive than casual acquaintances to the discussion of sensitive issues. Simultaneously, this may require schools to work with other agencies to develop 'shared' venues and activities outside the school, so that the goals of shared education can be supported and complemented by opportunities for social contact in the community.

Secondly, those with responsibility for such programmes might also reflect on the formal mechanisms for introducing matters of difference within shared education. While the 
development of more numerous, stronger friendships may facilitate greater discussion of contentious issues, the entrenchment of avoidance norms in Northern Ireland may mean that this alone is insufficient. With this in mind, staff might consider how they can facilitate such discussions through mixed classes and activities while minimising anxiety about the possible threat to intergroup harmony. This may involve exploring how teachers can exploit opportunities to raise difference in their own subject, as well as considering alternative approaches to creating a space for discussion - for example, by taking advantage of the compulsory nature of citizenship education to provide a joint citizenship programme alongside other shared classes. Staff should also consider how to encourage progression within these encounters: while it may be counter-productive to introduce particularly contentious issues at too early a stage (Donnelly, 2012; Dovidio, Gaertner and Saguy, 2009; Nagda and Derr, 2004), a plan for developing the discussions may help to reduce the risk that they do not progress beyond the least controversial subjects.

While it is hoped that these recommendations will help to maximise the potential of shared education, we recognise that educational initiatives represent only one component of a much wider process of peacebuilding in Northern Ireland. Whether the region's parallel school system is regarded as a cause or a consequence of social division, changes in education can only be effective if implemented alongside changes in related policy areas (housing, employment and policing, for example) and accompanied by effective equality legislation and political reform. While thus only one of a number of facets of any reconciliation programme, educational initiatives such as SEP can nonetheless make a distinctive contribution via their emphasis on relationship-building 'from the bottom up'. By providing opportunities for pupils to meet and form friendships, shared education provides an important complement to change at the elite level, helping to address the separation that persists on a day-to-day level within Northern Irish society.

To conclude, the current research adds to a growing body of literature (Donnelly, 2004, 2012; Dixon and Durrheim, 2003; Hemming, 2011) that demonstrates that positive outcomes from contact - in terms of relationship-development and reconciliation - cannot be assumed to result from proximity. While Allport recognised this in outlining four conditions of contact, and a number of other studies have done so in highlighting processes of resegregation (Alexander and Tredoux, 2010; Clack, Dixon and Tredoux, 2005), there remains a tendency to assume that the act of integrating schools or neighbourhoods will lead to interaction and, in 
turn, to positive relationships and changes in attitude. As this paper has demonstrated, however, effective integration is likely to require a more proactive approach, which in educational settings may mean encouraging interaction through the arrangement of the contact 'space' and the selection of tasks and activities. Furthermore, particularly in societies where group differences have been a cause of conflict, it may be unrealistic to imagine that these matters will be raised willingly by participants during interaction. Rather, this is likely to require considerable thought and skill from facilitators to ensure that participants can engage in dialogue in a supportive environment, without fear of provoking hostility or resentment. Given the complex recent history of Northern Ireland, and other similarly divided societies, it should not be surprising that a more nuanced and complex response is required. It is hoped that the current research can make a contribution in this direction.

\section{References}

Aiken, N. T. (2010). Learning to live together: Transitional justice and intergroup reconciliation in Northern Ireland, International Journal of Transitional Justice, 4, 166-188. doi:10.1093/ijtj/ijq002.

Alliance Party (2013, April 22 $\left.{ }^{\text {nd }}\right)$. Lunn comments on shared education report. Retrieved from: http://allianceparty.org/article/2013/0007788/lunn-comments-on-shared-educationreport.

Al Ramiah, A., Hewstone, M., Voci, A., Cairns, E. and Hughes, J. (2013). It's never too late for 'us' to meet 'them': prior intergroup friendships moderate the impact of later intergroup friendships in educational settings, British Journal of Educational Psychology, 83, 57-75. doi: 10.1111/j.2044-8279.2011.02054.x.

Alexander, L. and Tredoux, C., (2010). The spaces between us: A spatial analysis of informal segregation at a South African University, Journal of Social Issues, 66, 367-386. doi:10.1111/j.1540-4560.2010.01650.x.

Allport, G.W. (1958). The nature of prejudice, $2^{\text {nd }}$ edn. Garden City, NY: Doubleday Anchor. 
Braun, V. and Clarke, V. (2006). Using thematic analysis in psychology, Qualitative Research in Psychology, 3, 77-101. doi:10.1191/1478088706qp063oa.

Brown, R., Eller, A., Leeds, S. and Stace, K. (2007). Intergroup contact and intergroup attitudes: A longitudinal study, European Journal of Social Psychology, 37, 692-703. doi:10.1002/ejsp.384.

Catholic Bishops of Northern Ireland (2001). Building peace, shaping the future. Armagh: Archdiocese of Armagh.

Clack, B., Dixon, J. and Tredoux, C. (2005). Eating together apart: Patterns of segregation in a multi-ethnic cafeteria, Journal of Community and Applied Social Psychology, 15, 1-16. doi:10.1002/casp.787.

Connolly, P. (2000). What now for the contact hypothesis? Towards a new research agenda, Race, Ethnicity and Education, 3, 169-193. doi:10.1080/13613320050074023.

Conroy, J.C. (2001). A very Scottish affair: Catholic education and the state, Oxford Review of Education, 27, 543-558. doi:0.1080/03054980120086239.

Department of Education (2014). Promoting fundamental British values as part of SMSC in schools: Departmental advice for maintained schools. London: Department for Education.

Dixon, J. and Durrheim, K. (2003). Contact and the ecology of racial division: Some varieties of informal segregation, British Journal of Social Psychology, 42, 1-23. doi:10.1348/014466603763276090.

Dixon, J., Durrheim, K. and Tredoux, C. (2005). Beyond the optimal contact strategy: A reality check for the contact hypothesis, American Psychologist, 60, 697-711. doi:10.1037/0003-066X.60.7.697.

Dixon, J., Durrheim, K. and Tredoux, C. (2007). Intergroup contact and attitudes toward the principle and practice of racial equality, Psychological Science, 18, 867-872. doi:10.1111/j.1467-9280.2007.01993.x. 
Dixon, J., Durrheim, K., Kerr, P. and Thomae, M. (2013). 'What's so funny 'bout peace, love and understanding?' Further reflections on the limits of prejudice reduction as a model of social change, Journal of Social and Political Psychology, 1, 239-252.

doi:10.5964/jspp.v1i1.234.

Dixon, J., Levine, M., Reicher, S. and Durrheim, K. (2012). Beyond prejudice: Are negative evaluations the problem and is getting us to like one another more the solution? Behavioural and Brain Sciences, 35, 411-425. doi:10.1017/S0140525X11002214

Donnelly, C. (2004). What price harmony? Teachers' methods of delivering an ethos of tolerance and respect for diversity in an integrated school in Northern Ireland, Educational Research, 46, 3-16. doi:10.1080/0013188042000178782.

Donnelly, C. (2012). Defending identity and ethos: An analysis of teacher perceptions of school collaboration in Northern Ireland, Policy Futures in Education, 10, 540551. doi:10.2304/pfie.2012.10.5.540.

Dovidio, J.F., Gaertner, S.L. and Kawakami, K. (2003). Intergroup contact: The past, present, and the future, Group Processes and Intergroup Relations, 6, 5-21. doi:10.1177/1368430203006001009.

Dovidio, J.F., Gaertner, S.L. and Saguy, T. (2009). Commonality and the complexity of 'we': Social attitudes and social change, Personality and Social Psychology Review, 13, 3-20. Doi: doi:10.1177/1088868308326751.

Duffy, G. and Gallagher, T. (2015). Collaborative evolution: The context surrounding the formation and the effectiveness of a school partnership in a divided community in Northern Ireland, Research Papers in Education, 30, 1-24. doi:10.1080/02671522.2014.880731. 
Dugan, E. (2014, December 31) Government's obsession with faith and free schools 'breeds social and racial segregation. The Independent. Retrieved from:

http://www.independent.co.uk/news/education/education-news/faith-and-free-schools-breedsocial-and-racial-segregation-warns-leading-campaigner-9952374.html.

Emerson, L. (2012). Conflict, transition and education for 'political generosity': Learning from the experience of ex-combatants in Northern Ireland, Journal of Peace Education, 9, 277-295. doi:10.1080/17400201.2012.691076.

Erasmus, Z. (2010). Contact theory: Too timid for 'race' and racism, Journal of Social Issues, 66, 387-400. doi:10.1111/j.1540-4560.2010.01651.x.

Feddes, A.R., Noack, P. and Rutland, A. (2009). 'Direct and extended friendship effects on minority and majority children’s interethnic attitudes: A longitudinal study', Child Development, 80, 377-390. doi: 10.1111/j.1467-8624.2009.01266.x.

Flint, J. (2007). Faith schools, multiculturalism and community cohesion: Muslim and Roman Catholic state schools in England and Scotland, Policy and Politics, 35, 251-268.doi: $\underline{10.1332 / 030557307780712979 .}$

Flint, J. (2012). Catholic schools and sectarianism in Scotland: Educational places and the production and negotiation of urban space, Policy Futures in Education, 10, 507-517. doi:doi:10.2304/pfie.2012.10.5.507.

Forbes, H. (2004). Ethnic conflict and the contact hypothesis. In Y.T. Lee, C. McCauley, F. Moghaddam and S. Worschel (Eds.) The psychology of ethnic and cultural conflict (pp.6988). New York, NY: Praeger.

Gallagher, T. (2004). Education in divided societies. Basingstoke: Palgrave Macmillan.

Gallagher, T. (2005). Faith schools and Northern Ireland: A review of research, in R. Gardner, J. Cairns and D. Lawton (eds.) Faith schools: consensus or conflict? London: RoutledgeFalmer, 156-165. 
Grace, G. (2012). Faith schools: democracy, human rights and social cohesion, Policy Futures in Education, 10, 500-506. doi: 10.2304/pfie.2012.10.5.500.

Grayling, A.C. (2005, 15 July). Two words of warning: Northern Ireland. Times Educational Supplement. Retrieved from: http://www.tes.co.uk/article.aspx?storycode=2116736.

Halstead, J.M. and McLaughlin, T. (2005). Are faith schools divisive?, in R. Gardner, J. Cairns and D. Lawton (eds.) Faith schools: consensus or conflict? London: RoutledgeFalmer, $\underline{61-73 .}$

Hargie, O. (2014). Communication accommodation in a divided society: Interaction patterns between Protestants and Catholics in Northern Ireland, Studies in Communication Science, 14, 78-85. doi:10.1016/j.scoms.2014.03.005.

Harwood, J., Hewstone, M., Paolini, S. and Voci, A. (2005). Grandparent-grandchild contact and attitudes toward older adults: Moderator and mediator effects, Personality and Social Psychology Bulletin, 31, 393-406. doi:10.1177/0146167204271577.

Hemming, P.J. (2011). Meaningful encounters? Religion and social cohesion in the English primary school, Social and Cultural Geography, 12, 63-81.

doi:10.1080/14649360903514384.

Herek, G. M., \& Capitanio, J. P. (1996). 'Some of my best friends’: Intergroup contact, concealable stigma, and heterosexuals' attitudes toward gay men and lesbians. Personality and Social Psychology Bulletin, 22, 412-424. doi:10.1177/0146167296224007.

Home Office (2001). Community cohesion: A report of the Independent Review Team. London: Home Office.

Hughes, J. (2011). Are separate schools divisive? A case study from Northern Ireland, British Educational Research Journal, 37, 829-850. doi: 10.1080/01411926.2010.506943.

Hughes, J., Donnelly, C., Hewstone, M., Gallagher, T. and Carlisle, K. (2010). S.chool partnerships and reconciliation: An evaluation of school collaboration in Northern Ireland. Belfast: Queen’s University. 
Hughes, J., Lolliot, S., Hewstone, M., Schmid, K. and Carlisle, K. (2012). Sharing classes between separate schools: A mechanism for improving inter-group relations in Northern Ireland? Policy Futures in Education, 10, 528-539. doi:10.2304/pfie.2012.10.5.528.

Integrated Education Fund (2013) Baroness May Blood on shared education report: Integrated schools share every day. Retrieved from: http://www.ief.org.uk/debrief/baronessmay-blood-on-shared-education-report-integrated-schools-share-every-day.

Islam, M.R. and Hewstone, M. (1993). Dimensions of contact as predictors of intergroup anxiety, perceived outgroup variability, and outgroup attitudes: an integrative model, Personality and Social Psychology Bulletin, 19, 700-710. doi:10.1177/0146167293196005.

Jackman, M.R. and Crane, M. (1986). ‘Some of my best friends are black...’’ Interracial friendship and whites’ racial attitudes, Public Opinion Quarterly, 50, 459-486. doi:10.1086/268998.

Knox, C. (2010). Sharing Education Programme: Views from the white board. Jordanstown: Atlantic Philanthropies.

Maoz, I. (2011). Does contact work in protracted asymmetrical conflict? Appraising 20 years of reconciliation-aimed encounters between Israeli Jews and Palestinians, Journal of Peace Research, 48, 115-125. doi: 10.1177/0022343310389506.

Mears, I and Ibrahim, F. (2005, 19 August). Do we need more state faith schools? Times Educational Supplement. Retrieved from https://www.tes.co.uk/article.aspx?storycode=2124547.

Miller, H. (2001). Meeting the challenge: The Jewish schooling phenomenon in the UK, Oxford Review of Education, 27, 501-513. doi: 10.1080/03054980120086202.

Nagda, B.A. and Derr, A. (2004). Intergroup dialogue: Embracing difference and conflict, engendering community. In W. Stephan and P. Vogt (Eds.) Education programs for improving intergroup relations: Theory, practice research (pp.133-151). New York: Teachers College Press. 
Nagda, B.A., Yeakley, A., Gurin, P. and Sorensen, N. (2013). Intergroup dialogue: A criticaldialogic model for conflict engagement. In Tropp, L.R. (ed.) The Oxford handbook of intergroup conflict (pp.210-228). Oxford: Oxford University Press.

O’Connor, U., Hartop, B. and McCully, A. (2002). A review of the Schools Community Relations Programme. Bangor: Department of Education.

Pettigrew, T.F. (1997). Generalised intergroup contact effects on prejudice. Personality and Social Psychology Bulletin, 23, 173-185. doi:10.1177/0146167297232006.

Pettigrew, T.F. (1998). Intergroup contact theory. Annual Review of Psychology, 49, 65-85. doi:10.1146/annurev.psych.49.1.65.

Pettigrew, T.F. and Tropp, L.R. (2006). A meta-analytic test of intergroup contact theory, Journal of Personality and Social Psychology, 90, 751-783. doi:10.1037/0022-3514.90.5.751.

Pettigrew, T.F. and Tropp, L.R. (2008). How does intergroup contact reduce prejudice? Meta-analytic tests of three mediators, European Journal of Social Psychology, 38, 922-934. doi:10.1002/ejsp.504.

Richardson, N. (2011). Evaluating the Northern Ireland experience. In N. Richardson and T. Gallagher (Eds.) Education for diversity and mutual understanding: The experience of Northern Ireland (pp.331-351). Oxford: Peter Lang.

Rouhana, N. N. (2010) Key issues in reconciliation: Challenging traditional assumptions on conflict resolution and power dynamics. In D. Bar-Tal (Ed.) Intergroup conflicts and their resolution: A social psychological perspective (pp.291-314). New York: Psychology Press.

Saguy, T., Dovidio, J. F. and Pratto, F. (2008). Beyond contact: Intergroup contact in the context of power relations. Personality and Social Psychology Bulletin, 34, 432-445. doi: 10.1177/0146167207311200.

Saguy, T., Tropp, L. R. and Hawi, D. R. (2013). The role of group power in intergroup contact. In G. Hodson and M. Hewstone (Eds.) Advances in intergroup contact (pp.113-132). Hove: Psychology Press. 
Schofield, J. W. (1986). Black-white contact in desegregated schools. In M. Hewstone and R. Brown (Eds.) Contact and conflict in intergroup encounters (pp.79-92). Oxford: Blackwell.

SEP (2008). Schools working together [booklet]. Retrieved from

http://www.schoolsworkingtogether.co.uk/documents/sep-booklet.pdf.

Shah, S. (2012). Muslim schools in secular societies: persistence or resistance! British Journal of Religious Education, 34, 51-65. doi: 10.1080/01416200.2011.601897.

Skaar, E. (2013). Reconciliation in a Transitional Justice Perspective, Transitional Justice Review, 1, 54-103. doi:10.5206/tjr.2012.1.1.4.

Smith, A. and Robinson, A. (1996). Education for Mutual Understanding: The initial statutory years. Coleraine: University of Ulster.

Swart, H., Hewstone, M., Crisp, R. and Voci, A. (2011). Affective mediators of intergroup contact: A three-wave longitudinal study in South Africa, Journal of Personality and Social Psychology, 101, 1221-1238. doi:10.1037/a0024450.

Tam, T., Hewstone, M., Kenworthy, J. and Cairns, E. (2009). Intergroup trust in Northern Ireland, Personality and Social Psychology Bulletin, 35, 45-59. doi:10.1177/0146167208325004.

Tam, T., Hewstone, M., Harwood, J., Voci, A. and Kenworthy, J. (2006). Intergroup contact and grandparent-grandchild communication: The effects of self-disclosure on implicit and explicit biases against older people, Group Processes and Intergroup Relations, 9, 413-429. doi:10.1177/1368430206064642.

Turner, R.N., Hewstone, M. and Voci, A. (2007). Reducing explicit and implicit outgroup prejudice via direct and extended contact: The mediating role of self-disclosure and intergroup anxiety, Journal of Personality and Social Psychology, 93, 369-388. Doi:10.1037/0022-3514.93.3.369. 
Turner, R.N., Hewstone, M., Voci, A., Paolini, S., and Christ, O. (2007). Reducing prejudice via direct and extended cross-group friendship, European Review of Social Psychology, 18, 212-255. doi: 10.1080/10463280701680297.

Wright, S.C. and Lubensky, M.E. (2009). The struggle for social equality: Collective action versus prejudice reduction. In S. Demoulin, J.P. Leyens and J.F. Dovidio (Eds.) Intergroup misunderstandings: Impact of divergent social realities (pp.291-310). New York: Psychology Press. 